\title{
STRATEGIES OF LUXURY BRANDS AFTER CORONAVIRUS
}

\author{
Doina I. POPESCU ${ }^{a}$, Eduard Gabriel CEPTUREANU ${ }^{b}$, Sebastian Ion CEPTUREANU \\ ${ }^{a, b, c}$ Bucharest University of Economic Studies, Romania
}

DOI: $10.24818 / \mathrm{IMC} / 2020 / 03.04$

\begin{abstract}
This work presents the impact of the economic crisis, caused by the sanitary crisis, on the luxury industry at a global level. Hence, we show the effects of broken supply chains, business globalization, store closure, customers' income reduction and decline of tourism on the luxury industry. Within this article, the short, medium- and long-term actions that need to be taken by luxury brand managers are presented. In addition, social responsibility actions performed by luxury brands for the public good are described.
\end{abstract}

KEYWORDS: coronavirus, economic crisis, luxury brands, social responsibility, strategies.

\section{INTRODUCTION}

During an economic crisis, and also in its aftermath, usually expenditure is cut down and concerns are raised about safeguarding the financial future, certain consumption patterns change, and in some cases, more is paid for new desires and priorities (Todor, 2009; Popescu, 2009), which even leads to the paradox that in hard times many pay for new considerations regarding lifestyle. Many promoters of focusing on customer satisfaction have constantly argued that people increasingly appreciate results rather than products, the product becoming a part of the solution to a personal or business challenge or being a mandatory experience. The value hence derives from the help provided so that the person is able to see the solution. Similarly, numerous brands (sets of expectations that consumers/customers have when consuming/thinking about the 'consumption' of the good or service, branding being the process of brand creation) are perceived as non-differentiated means of reaching a given end, being purchased based on a compromise between price and convenience. For example, the financial recession of 2008 appears to have augmented this non-differentiated perception of brands. If desire comes from expectation or from the experience of an emotionally satisfying result, experience appears to become an end in itself. Clients cannot, however, purchase better until they know what is better (Popescu, 2017a; Popescu, 2017b).

In the context of dramatically shifting management and marketing (with a preoccupation for the financial future, physical distancing, time, markets and competition), we are participants and spectators to experiential marketing (the integration of the brand or of product messages in consumers' lives under the form of interactive experiences, rather than their delivery via inert traditional media, such as the printed press or television) versus experiential branding (beneficial differentiation of a good/service in someone's mind by concentrating on the wholeness of the experience, rather than on characteristics, attributes or product benefits).

If a brand strategy consists in a set of plans for product differentiation from competition and communicating these differences on the market, to count on brand equity equates to the existence of an amount estimated by premium customers, willing to pay it for a "branded" product versus an "unbranded" competitor.

\footnotetext{
* Corresponding author.E-mail address: doina.popescu@man.ase.ro
} 
There is also the question of why a client changes brands despite efforts made, considering the fact that customer retention is an important purpose of the business. A general brand change model shows how consumers use internal assessments of satisfaction and brand change barriers in order to reach brand selection decisions (Richarme, 2006). Satisfaction is a complex, intensely studied construct, explaining only around one quarter of the variation in customer retention indicators. The barriers of brand change have not been amply researched, even though they represent over 30\% of the variation in the same dependent construct (Purcărea \& Ioan-Franc, 2009).

Björn Ivens argues in his book "L'impact de la crise sur les marchés, les prix, les clients" that crisis marketing does not exist, marketing tools being the same, and strategic options being the same. If, in a time of growth, any actor in a market can take advantage of the expansion of demand (it is "only" about ensuring their share of market growth, an enterprise often being able to grow even without sophisticated marketing), in time of stagnation / crisis, market share needs to be defended and customer relations must be strengthened, marketing becoming primary (when the general budget is restricted, effective and efficient marketing is required).

Ivens, starting from the fact that marketing (a processes system according to Figure 1) is a matter of conviction, emphasizes the existence of two possibilities: either management considers that the marketing budget renders positive effects, or is convinced of the futility of spending money on marketing. If an enterprise believes that the budget enables market stimulation, then it must not be reduced in times of crisis, because now you have to make available resources for: defending market shares, developing new offers, improving existing offers, seeking to win new customers, stabilizing relations with current customers, being more visible than the competition.

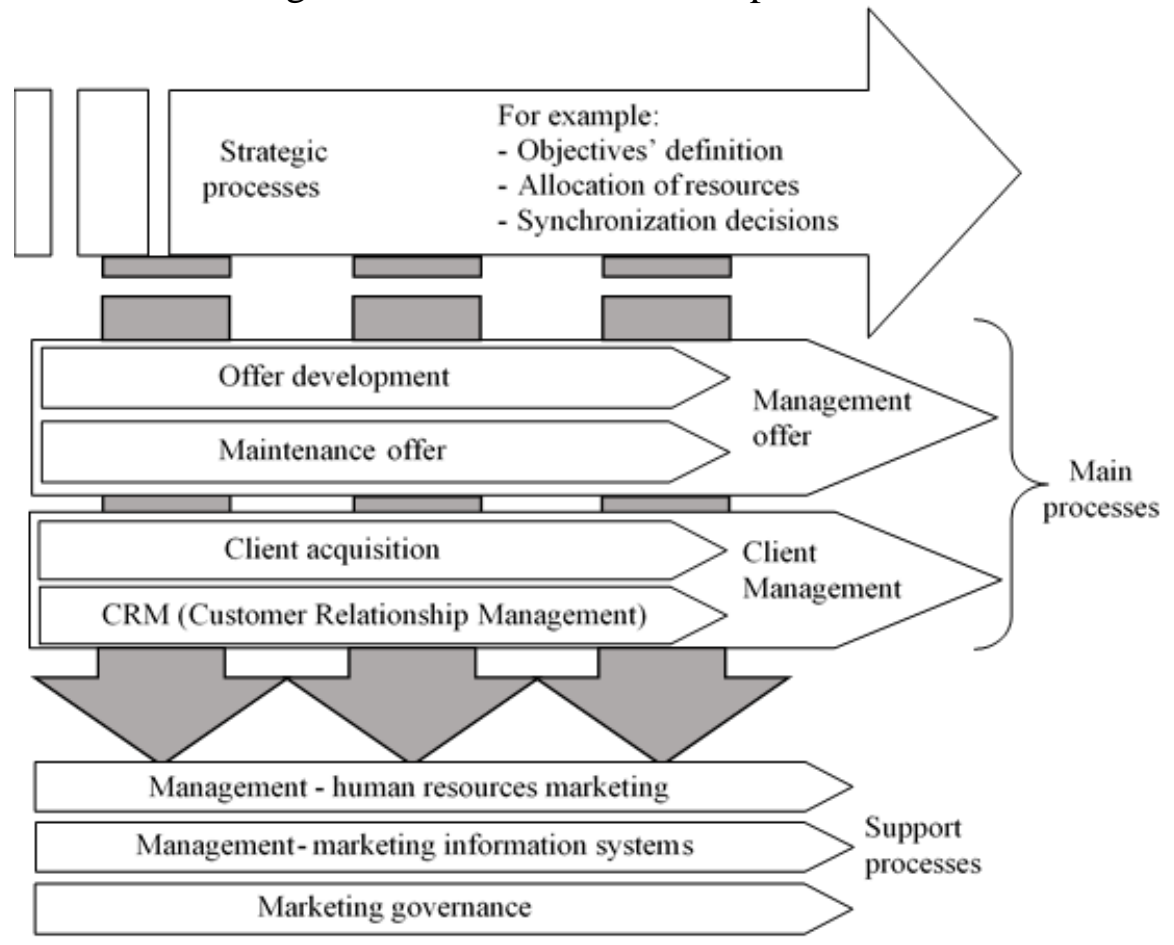

Figure 1. Marketing - a process system

Source: Björn Ivens, L'impact de la crise sur les marchés, les prix, les clients, Faculté des HEC, Université de Lausanne, Mardi, 2 Juin, 2009

Björn Ivens emphasizes that maintaining close contact with customers in times of crisis is essential (Ivens, 2009). 


\section{LUXURY BRANDS AND SOCIAL RESPONSIBILITY DURING THE CORONAVIRUS PANDEMIC}

One of the stages in elaborating a company's strategy is the setting of objectives. Hence, three main categories of objectives can be formulated: financial, marketing and societal (Popa et al., 2015).

In times of crisis, societal objectives acquire new meanings and must become a priority for companies (Popescu, 2018). Societal objectives include objectives related to environmental protection and sustainable development, as well as objectives regarding social responsibility and partnerships.

The objectives related to environmental protection and sustainable development are:

- Pollution reduction through the promotion of "green products" and use of processes that respect and preserve the environment;

- Collaboration and cooperation with all the members of the distribution chain that support ecological marketing.

The objectives regarding social responsibility and partnerships are meant to ensure:

- The company gains a positive image;

- The support - financial and via marketing actions - of charitable work, community projects or human rights societies;

- Communication with partners, in order to understand their preoccupations in respect of social actions taken (Burk Wood, 2005).

During the coronavirus pandemic, luxury brands acted urgently for the public good. Hence, Prada, LVMH, Armani, Valentino produced masks, disinfectant solutions or donated money to hospitals and non-profit organisations.

At the beginning of May, CR Runway initiated the project FASHIONUNITS, a fashion event organised by Derek Blasberg, Youtube channel head of fashion \& beauty, and directed by Carine Roitfeld, former editor-in-chief at Vogue Paris. It was a virtual fashion show, filmed at home by some of the most renowned names of international fashion, and was meant to be a manifesto of the fashion industry in support of the super-heroes fighting against COVID-19 in hospitals. Behind the Youtube fashion show was amfAR, a research foundation for AIDS and other infectious diseases that has organised charitable galas in Cannes, Los Angeles, New York, Paris and Milan, with the exceptional participation of fashion, music and cultural personalities. The virtual event was organised for fundraising for medics, nurses, as well as for finding a vaccine against COVID-19.

Along with famous supermodels who walked their home runways for this cause, TV celebrities such as Kim Kardashian, designers such as Diane von Fürstenberg, Alexander Wang, Riccardo Tisci, Brandon Maxwell, Pierpaulo Piccioli, Maria Grazia Chiuri and many others also took part in the event.

The models made up and hair-styled themselves, following the advice of make-up and hair artists, and chose to wear outfits from their own wardrobe for the show.

The models walked the runway with puppies, babies and parrots and the event ended in a round of applause. It was a moving show, filled with beautiful pictures and framings from nature (the models' homes or gardens), great spontaneity and humanity, encouraging messages sent to first line workers, but also nostalgia for real fashion shows, embraces and seeing loved ones once more (Turp-Balazs, 2020a).

In addition, fashion house Valentino has launched a charity project for Lazzaro Spallanzani Hospital in Rome, called \#ValentinoEmpathy, conceived by Pierpaolo Piccioli, the creative director of the brand. Valentino is the first high scale luxury brand launching a campaign at home for its autumn 2020 collections. Thus, the brand has launched a campaign made at home with many of its muses, to celebrate its autumn 2020 collections and connect people in this difficult time. Among the celebrities taking part are Gwyneth Paltrow, Christy Turlington, Laura Dern, Laetitia Casta, Rossy 
de Palma and many of the brand's long-term collaborators, who will be photographed wearing Valentino not by professional photographers, but by the people closest to them. And while each of these celebrities dedicated time to the campaign, Valentino announced that the 1 million euro amount which would have been spent on advertising will be donated to the Lazzano Spallanzani National Institute, a hospital for infectious diseases in Rome.

Pierpaolo Piccioli's fashion-designer vision is to express his dreams and the concept of inclusion through his collections. His belief is that, even though we miss human touch, we are always connected through empathy, as we are all made of emotions (Turp-Balazs, 2020b).

Valentino fashion house is owned by the investment fund Mayhoola from Qatar, whose portfolio also includes the brands Balmain and Pal Zileri. Mayhoola and Valentino have additionally donated two million euro to the Italian hospital Sacco, one million euro to the French charitable organisation La Fondation Hôpitaux de Paris and one million to the Spanish field hospital set up at an exhibition center in Madrid.

Furthermore, beyond charitable work, still in connection with companies' and luxury brands' social responsibility, these are the ones that millions of people depend on, from workers in suppliers' factories up to store employees and craftsmen. In this context, luxury brand managers need to respond to strategic questions related to the future of their business.

In virtual meetings organised by Vogue publications worldwide with famous designers, Valentino's creative director considers that, in difficult situations, more creative ideas can be born, and in this context he believes that creativity, not marketing, will dictate the fashion system (Aileni et al., 2020). Pierpaolo Piccioli considers that people are at the core of the fashion creative process, even though branding and the power of money have sometimes been dominant. He ponders that fashion needs to be less competitive, as rankings such as "Best 10 shows" or "Top 10 looks" are not important. Consequently, a system needs to be created for quality, not quantity.

\section{STRATEGIES OF LUXURY BRANDS AFTER THE CORONAVIRUS}

Even if it is early to quantify the full impact of COVID-19 on the luxury sector, one can say that it has already shattered some fundamental aspects, some over the long term. Independent wholesalers from the luxury market, many of whom had small boutiques or family-owned companies, had been affected even before the coronavirus, especially due to the increase in online shopping and the vertical integration of brand distribution. The crisis could take some of them out of the game, as well as new-entrant designers, who need to sell in order to finance their collections. As a consequence, in order to survive, boutique owners could adopt an aggressive discount trade, which could damage luxury brands' positioning.

The luxury sector addresses a global consumer, seeing that $20-30 \%$ of the industry's income is generated by customers buying outside of their origin countries.

Thus, according to "The State of Fashion 2020 Coronavirus Update” report prepared by McKinsey, in 2018, the Chinese have made over 150 million trips abroad, and over half of their luxury purchases have been made outside of Asia. The reason is not only the lower European prices, but also that shopping has become an integral part of the travel experience, and to purchase a brand in its origin country renders a feeling of authenticity and excitement.

Chinese consumers still remain the most important growth factor of this sector, but luxury brands will need to approach them in their origin country, even after restrictions are lifted, because tourism is, and will continue to be, in decline. Hotels, resorts, cruise ships and high-end restaurants all fall into the luxury experience, one of the most dynamic sectors prior to COVID-19. Seeing that luxury as an experience is registering a decline, consumers are and will be turning towards the purchase of luxury products, instead of luxury services. Hence, measures such as creating local experiences, consolidating digital offers and omnichannel and closer communication with consumers, even with those from secondary Chinese cities, could be beneficial. 
In the past decade, European luxury conglomerates such as LVMH or Kering, private equity companies or Middle Eastern investors have been purchasing high end brands. McKinsey estimates that in the current conditions, those without experience on the luxury market could realise they do not have the required competencies to manage such companies post-crisis, and acquisitions which used to be very expensive could now become accessible. Thus, it will all depend on brands' ability to withstand urgent challenges, at the same time preparing themselves for the future (Imran et al., 2020).

The immediate priorities for luxury brands should be:

- To review their inventory for 2020 and rethink their collections for 2021;

- To accelerate investments in the digital area and engage consumers;

- To sell without discounts, which damage the brand image;

- Cash flow management;

- To review leasing contracts and all operational expenses, at the same time supporting shops, suppliers and paying attention to the support offered by governmental authorities in each country;

- To adjust income and profitability forecasts and create incentives for business unit managers in order to establish new targets (an approach fixed on sales would probably lead to an indexation of projected demand and, consequently, to large quantities of unsold inventory).

With regard to 2020 spring collection sales, these have fallen with up to $70 \%$ in the context of store closure and a decrease in customers' income. Brands need to sell their inventory without resorting to discounts, and furthermore, they could use their extra inventory to offer their loyal clients small gifts or surprises, in order to maintain their shopping appetite.

As many stores were closed and are about to be closed once more in many countries, it is vital to focus on online trade in order to continue selling and communicating with customers. McKinsey recommends brands, apart from selling via their own websites, to consider partnerships with etailers with tradition and good reputation.

Among the potential strategies which could be adopted by luxury brands in the next period one can enumerate:

- Stablishing the business in times of crisis;

- A higher propensity towards the digitalization of the supply chain, via online trade and the exploration of new partnerships with well-established online retailers;

- The use of virtual booths and digital sampling in the context of reduced travel;

- Developing competencies within companies which could help the business during other potential crises;

- Rethinking the business model and considering potential mergers or acquisitions;

- Vertical integration via acquisitions of manufacturing capabilities, which would mean maintaining inhouse tradition and expertise in the context in which many retailers have been left without stock due to the breakage of supply chains and business globalization;

- Anticipating consumer behaviors.

Over $40 \%$ of the global production of luxury goods is made in Italy, one of the worst stricken countries by the coronavirus pandemic, and all these Italian family businesses were shut down. Luxury companies should assess, per each product category, where the impact will be felt the most acutely. Short term actions could consist in moving inventories per regions and channels, prioritising less affected geographical markets and ensuring the fulfilment of online orders. In the medium term, companies should help their production partners redress, by paying promptly and reopening production as quickly as possible. If these companies disappear, the craftsmanship they have earned from generation to generation will be lost forever.

Fashion weeks and fairs are essential means by which brands have maintained their relationship with consumers and commercial partners. Before coming back to normal, brands activating in the 
luxury industry, in close collaboration with the organizers of fashion weeks and fairs, should explore alternatives to emanate the same kind of magic offered by such events, in the time of restrictions on travel and gatherings.

With regards to consumption habits, some brands have reported that, in the luxury segment, the most expensive and the cheapest products could be more resilient than the intermediate ones. Bags and small leather articles could sell better than the ready-to-wear ones during the crisis, and this includes children's articles. Also, it is observed that millennials have not decreased expenses so much as the rest of the customers (Turp-Balazs, 2020c).

Moreover, a consumption preference which could prevail after the crisis, seeing previous experiences after similar economic crises, is the intensification of sustainability (Popescu, 2019; Popescu, 2018; Ceptureanu et al., 2020; Završnik \& Potočan, 2020). Thus, clients will want to consume more responsibly. This is the reason why luxury brands will need to attach importance to the transparency of their processes and products. Also, from the experience of the latest financial crisis, clients pursued a more classical side of luxury, based on craftsmanship and tradition, as opposed to "bling".

\section{CONCLUSIONS}

The current work identifies possible strategies which could be adopted by luxury brands during and after the sanitary crisis caused by the new coronavirus. Relying on experience accumulated from prior economic crises, the trends that prevail post-crisis are the focus on creativity and innovation, quality, and intensification of sustainability. In this context, luxury brand managers will need to rethink their business model, re-use technology to a greater extent, and give importance to the transparency of their processes and products.

\section{REFERENCES}

Aileni, R. M., Chiriac, L., Surdu, L. \& Rădulescu, R., I. (2020). Field research and methodologies for textile industry innovation in the context of European economy. Industria Textilă, 71(1).

Burk Wood, M. (2005). Marketing planning. Stratégie mise en oeuvre et contrôle. Paris, France : Pearson Education.

Ceptureanu, S. I., Ceptureanu, E. G., Popescu, D. I. \& Orzan, O. A. (2020). Eco - innovation Capability and Sustainability Driven Innovation Practices in Romanian SMEs. Sustainability, 12(17).

Imran, A., Balchandani, A., Berg, A., Hedrich, S., Ekeløf Jensen, J. \& Rölkens, F. (2020). It’s time to rewire the fashion system: State of Fashion coronavirus update. Retrieved July 21, 2020, from

https://www.mckinsey.com/industries/retail/our-insights/its-time-to-rewire-the-fashion-systemstate-of-fashion-coronavirus-update

Ivens, B. (2009). L'impact de la crise sur les marchés, les prix, les clients. Faculté des HEC: Université de Lausanne.

Popa, I., Ștefan, S. C. \& Popescu, D. I. (2015). A Pilot Study on Management System Implemented within Romanian Organizations. Proceeding of 26th International Business Information Management Association Conference, Innovation Management and Sustainable Economic Competitive Advantage: From Regional Development to Global Growth, Madrid.

Popescu, D. I. (2019). Social Responsibility and Business Ethics IX. Green Management and Sustainable Development of the Firm. Quality-Access to Success, 20(168).

Popescu, D. I. (2018). Social Responsibility and Business Ethics VI. Redefining Company Strategy in the New Socio-Economic Context. Quality-Access to Success, 19(162). 
Popescu, D. I. (2017a). Social Responsibility and Business Ethics IV. Social Responsibility and Process driven by Customer. Quality-Access to Success, 18(160).

Popescu, D. I. (2017b). Social Responsibility and Business Ethics II. Corporate Social Responsibility between Intent and Reality. Quality- Access to Success, 18(158).

Popescu, D. I. (2009). Competitive advantage assuring within clothing manufacture companies in Romania. Industria Textilă, 60(3).

Purcărea, T. V. \& Ioan-Franc, V. (2009). Provocări pentru managementul marketingului în timp de criză. La ora judecăților înțelepte bazate pe valoare și logică. Marketing - Management, Studii, Cercetări, Consulting, 3-4.

Richarme, M. T. (2006). Incorporatin an affective component to a cognitive model of brand switching barriers. University of Texas at Alington.

Todor, J. (2009). People will Consume Less but Aim to Consume Better. Retrieved September, 21, 2020 ,

from

http://www.customerthimg.com/blog/people_will_consume_less_but_aim_to_consume_better

Turp-Balazs, A. (2020a). Show virtual în vreme de COVID împotriva COVID. Dialog Textil.

Turp-Balazs, A. (2020b). Valentino Empathy, o campanie făcută acasă la vedete. Dialog Textil.

Turp-Balazs, A. (2020c). Industria luxului după coronavirus - achiziția furnizorilor, o soluție?. Dialog Textil.

Završnik, B. \& Potočan, V. (2020).za Clothing fashion brands. Industria Textilă, 71(5). 